\title{
Pengaruh Senam Prenatal Yogaterhadap Kejadian Pre Eklampsia pada Ibu Hamil Trimester III di Puskesmas Wilayah Kerja Dinkes Kota Bandar Lampung
}

\section{The Effect of Prenatal Yoga Gymnastics on the Incidence of Pre Eclampsia in Pregnant Women in Trimester III at the Community Health Center Working Area of the Health Office of Bandar Lampung City}

\author{
Rosmadewi Rosmadewi ${ }^{1}$, Novita Rudiyanti ${ }^{1, \bowtie}$ \\ ${ }^{1}$ Jurusan Kebidanan, Politeknik Kesehatan Tanjung karang, Indonesia \\ 1,® Coresponding author: rudiyantinovita@yahoo.com
}

\begin{abstract}
Kata kunci:
Pre eklampsia,

Senam prenatal Yoga

Abstrak

Latar belakang: Pre eklampsi-eklampsi merupakan komplikasi kehamilan dan persalinan yang dapat menyebabkan kematian ibu bersalin. Pencegahan pre eklampsi diantaranya dapat dilakukan dengan senam prenatal Yoga. Tujuan: Tujuan penelitian ini adalah untuk mengetahui pengaruh senam prenatal Yoga terhadap kejadian pre eklampsi pada ibu hamil Trimester III di Puskesmas wilayah kerja Dinkes Kota Bandar Lampung tahun 2017. Metode: Penelitian ini adalah quasi eksperimen dengan rancangan Kohort dengan subyek ibu hamil trimester ke II (usia kehamilan lebih dari 28 minggu). Sampel penelitianadalah ibu hamil usia kehamilan 28 - 32 minggu yang berada di wilayah Puskesmas Way Kandis dan Puskesmas Raja Basa Indah Kota Bandar Lampung tahun 2017yang berjumlah sampel 84 orang.Datadianalisis secara univariat dan bivariat menggunakan uji chi square. Hasil: Hasil penelitian menunjukkan ada pengaruh senam prenatal Yoga terhadap kejadian pre eklampsia pada ibu hamil trimester III (p value 0,035 ; $R R=2,46$ ). Simpulan: Senam prenatal Yogamampu mencegah kejadian pre eklampsia pada ibu hamil trimester III. Upaya yang perlu dilakukan bidan dan puskesmas untuk memprogramkan pelaksanaan senam prenatal Yoga dimulai pada awal trimester II baik di Puskesmas maupun di Poskeskel untuk mencegah kejadian pre eklampsia.
\end{abstract}

Keyword:

Pre eclampsia, Prenatal Yoga exercises.

\begin{abstract}
Background: Preeclampsia is a complication of pregnancy and childbirth which can cause maternal death. Pre-eclampsia prevention can be done with prenatal Yoga exercises. Purpose: The purpose of this study was to determine the effect of prenatal Yoga gymnastics on the incidence of pre-eclampsia in trimester III pregnant women in the Puskesmas in the working area of Bandar Lampung City Health Office in 2017. Methods: This study uses a cohort design. The sample of the study were pregnant women 28-32 weeks of gestation in the Way Kandis Health Center and Raja Basa Indah Health Center in Bandar Lampung City in 2017, totaling 84 people. Data were analyzed by univariate and bivariate using chi square test. Results: The results showed that there was an effect of prenatal Yoga gymnastics on the incidence of pre eclampsia in third trimester pregnant women ( $p$ value 0.035; $R R=2.46$ ). Conclusion: Prenatal Yoga exercises can prevent pre-eclampsia in third trimester pregnant women. Efforts need to be made by midwives and health centers to program the implementation of prenatal Yoga exercises starting at the beginning of the second trimester both at the Puskesmas and at the Health Post to prevent the occurrence of pre-eclampsia.
\end{abstract}

Copyright $@ 2018$ Jurnal Kesehatan Metro Sai Wawai. All rights reserved. 


\section{Pendahuluan}

Angka kematian ibu (AKI) merupakan salah satu indikator derajat kesehatan suatu bangsa. Menurut Survei Demografi dan Kesehatan Indonesia (SDKI) tahun 2012, angka kematian ibu berkisar 359 per 100.000 kelahiran hidup. Menurut data Kementerian Kesehatan (Kemenkes) pada tahun 2015 tercatat ada 305 ibu meninggal per 100 ribu orang. Berdasarkan data tersebut terlihat bahwa target yang ditetapkan pada Millennium Development Gols (MDGs) pada tahun 2015, angka kematian ibu diharapkan 102 per 100.000 kelahiran hidup tidak tercapai. Angka kematian ibu di Indonesia tergolong masih tinggi bila dibandingkan dengan Negara-Negara Asean lainnya, antara lain Singapura 6/100.000 kelahiran hidup, Malaysia 160/100.00 kelahiran hidup, Vietnam 160/100.000 kelahiran hidup, Filipina 112/100.000 kelahiran hidup dan Brunai 33/100.000 kelahiran hidup (Kemenkes RI, 2015).

Penyebab tingginya angka kematian ibu di Indonesia antara lain disebabkan perdarahan 30,3\%, hypertensi dalam kehamilan (pre eklampsia) $27,1 \%$, infeksi 7,3\% dan lain-lain 40,3\%. Penyebab lainlain adalah penyebab kematian ibu tidak langsung, seperti penyakit kanker, ginjal, jantung, tuberculosis atau penyakit lain yang diderita ibu. Salah satu penyebab yang sulit diantisipasi adalah terjadinya kejadian pre eklampsia karena penyebab terjadinya pre eklampsia sampai saat ini belum diketahui. Dilihat dari status kesehatan perempuan, khususnya ibu hamil. Sekitar 28,8\% ibu hamil menderita hipertensi dan 32,9\% ibu hamil mengalami obesitas. Hipertensi bisa mengakibatkan gangguan kardiovaskular yang menjadi faktor penyebab kematian pada ibu saat melahirkan. (Kemenkes RI, 2016)

Preeklampsi merupakan komplikasi kehamilan dan persalinan yang ditandai dengan peningkatan tekanan darah, protein urine dan oedema yang kadang-kadang disertai dengan kejang sampai koma. Sindroma pre eklampsi ringan sering tidak diperhatikan sehingga tanpa disadari dalam waktu singkat dapat timbul pre eklampsi berat bahkan eklampsia (Prawirohardjo, Anwar, Baziad, \& Prabowo, 2011). Faktor yang mempengaruhi terjadinya pre eklampsia diantaranya primigravida terutama primigravida muda, Distensi rahim berlebihan seperti hidramnion, hamil ganda, mola hidatidosa, Penyakit yang menyertai kehamilan seperti jantung, diabetes mellitus, kegemukan, umur ibu saat hamil diatas 35 tahun. Kejadian pre eklampsi berkisar antara 3\% - 5\% dari kehamilan yang di rawat (Manuaba, I. A, 2009). Penelitian Dessy Hasmawati menyebutkan ada hubungan usia ibu, paritas, dan penyakit penyerta dengan kejadian pre eklampsi. Tidak ada hubungan usia kehamilan dengan kejadian pre eklampsi RSUD Embung Fatimah Kota Batam Tahun 2012 (Hasnawati, 2014). Penelitian Sri Fuji Astuti adanya hubungan yang signifikan antara usia ibu, status pendidikan ibu, dan riwayat penyakit hipertensi dengan kejadian preeklampsia. Sedangkan, faktor yang tidak berhubungan yaitupekerjaan, pemeriksaan antenatal care, jumlah paritas, jarak kehamilan, riwayat komplikasi kehamilan dan riwayat penyakit Diabetes mellitus di Wilayah Kerja Puskesmas Pamulang Kota Tangerang Selatan Tahun 20142015 (Hastuti, 2015).

Pre eklampsi dapat mengalami spasme pembuluh darah disertai dengan retensi garam dan air. Pada biopsy ginjal ditemukan spasme hebat arteriola glomerulus. Pada beberapa kasus, lumen arteriola sedemikian sempitnya sehingga hanya dapat dilalui oleh satu sel darah merah. Jadi, jika semua arteriola dalam tubuh mengalami spasme, maka tekanan darah akan naik, sebagai usaha untuk mengatasi kenaikan tekanan perifer agar oksigenasi jaringan dapat dicukupi. Sedangkan kenaikan berat badan dan edema yang disebabkan oleh penimbunan air yang berlebihan dalam ruangan interstisial belum diketahui sebabnya, mungkin karena retensi air dan garam. Proteinuria dapat disebabkan oleh spasme arteriola sehingga terjadi perubahan pada glomerulus (Prawirohardjo, Anwar, Baziad, \& Prabowo, 2011).

Terjadinya spasme pada pembuluh darah dan penimbunan cairan yang berlebihan, salah satunya dapat diatasi dengan melakukan senam pada masa kehamilan. Senam hamil sebaiknya dilakukan semenjak usia kehamilan 20 minggu dan satu minggu dilakukan 2 kali. Manfaat dari senam hamil antara lain memperbaiki sirkulasi darah dan mengurangi bengkak-bengkak pada ibu hamil sehingga peningkatan tekanan darah dan terjadinya oedema dapat diantisipasi. 
Kasus kematian ibu di Provinsi Lampung pada tahun 2015 berjumlah 149 kasus, yang disebabkan oleh perdarahan 46 orang, hypertensi dalam kehamilan sebanyak 35 kasus, infeksi sebanyak 7 kasus, gangguan sistem peredaran darah sebanyak 10 kasus, gangguan sistem metabolik sebanyak 3 kasus dan lain-lain sebanyak 48 kasus (Dinkes Provinsi Lampung, 2015). Sedangkan,kasus kematian ibu di kota Bandar Lampung pada tahun 2014 kejadian kematian ibu sejumlah 7 kasus yang disebabkan oleh perdarahan post partum 1 kasus, pre eklampsia dan eklampsia 3 kasus, penyakit jantung dan ginjal 1 kasus, ileus paralitik 1 kasus dan penyakit hepatitis dan paru-paru 1 kasus (Dinkes kota Bandar Lampung, 2014). Berdasarkan data tersebut diatas, terlihat kasus kematian ibu di Kota Bandar Lampung yang terbanyak disebabkan oleh pre eklampsi dan eklampsi.

Kasus kematian ibu di wilayah Dinas Kesehatan Kota Bandar Lampung pada tahun 2014 sebanyak 7 kasus dari $20.427 \mathrm{KH}$, yang menjadi penyebab adalah gagal ginjal dan jantung 1 (satu), ilius paralitik 1 (satu), eklampsia 2 (dua) kasus, perdarahan post partum 1 (satu) kasus, hepatitis dan paruparu 1 (satu) kasus dan Impending Eklampsi sebanyak 1 (satu) kasus. Berdasarkan wilayah kejadian kasus kematian ibu, terjadi di wilayah kerja Puskesmas Puskesmas Kupang Kota 1 kasus, Puskesmas Way Kandis 2 kasus, wilayah Puskesmas Raja Basa Indah 1 kasus, wilayah Puskesmas Labuhan Ratu 1 kasus, Puskesmas Way Halim 1 kasus dan wilayah Puskesmas Way Laga 1 kasus (Dinkes kota Bandar Lampung, 2014). Hal tersebut menunjukkan bahwa penyebab terjadinya kasus kematian ibu di Kota Bandar Lampung yang terbesar disebabkan oleh pre eklampsia dan jumlah kematian ibu terbanyak di wilayah Puskesmas Way Kandis. Artikel ini dari hasil penelitian yang bertujuan untuk mengetahui pengaruh senam prenatal Yoga terhadap kejadian pre eklampsia pada ibu hamil trimester III di Puskesmas Wilayah Kerja Dinkes Kota Bandar Lampung Tahun 2017.

\section{Metode}

Penelitian ini menggunakan metode penelitian kuantitatif dengan menggunakan desain Kohort. Rancangan penelitian untuk membuktikan pengaruh senam prenatal Yoga terhadap kejadian pre eklampsia pada ibu hamil trimester III.

Populasi adalah ibu hamil dengan usia kehamilan 14-28 minggu yang berada di wilayah Puskesmas Way Kandis dan Puskesmas Raja Basa Indah Kota Bandar Lampung tahun 2017. Sampel yang diambil adalah sebagian dari ibu hamil di wilayah Puskesmas Way Kandis dan Puskesmas Raja Basa Indah Kota Bandar Lampung tahun 2017 sebanyak 42 orang. Teknik sampling pengambilan sampel menggunakan teknik simple random sampling.Kriteria: (a) Ibu hamil yang berada di wilayah Puskesmas Way Kandis dan Puskesmas Raja Basa Indah Kota Bandar Lampung; (b) Tercatat dalam buku kunjungan ibu hamil; (c). Usia kehamilan $\geq 14$ minggu dan $<28$ minggu dan; (d). Tekanan darah normal, (e) Proteinuria negatif.

Pengumpulan data menggunakan kuesioner untuk memperoleh data dari masing-masing varabel penelitian. Pada penelitian ini menggunakan tiga variabel, yaitu variabel independen, variabel dependen dan variabel confounding. Variabel independen dalam penelitian ini adalah prenatal Yoga. Sedangkan, variabel dependen adalah kejadian pre eklampsia dan variabel conponding adalah usia, paritas, jarak kehamilan, riwayat pre eklampsia, dan kegemukan. Analisis data untuk membuktikan pengaruh senam prenatal Yoga terhadap kejadian pre eklampsia pada ibu hamil menggunakan chi square dengan tingkat kemaknaan $(\alpha) 0,05$.

\section{Hasil}

\section{Gambaran responden}

Gambaran responden pada tabel 1 memperlihatkan dari 42 orang ibu hamil yang melakukan senam prenatal Yoga terdapat 7,14\% dan yang tidak mengalami kejadian pre eklampsia pada kehamilan trimester III 92,86\%. 
Tabel 1.

Distribusi Kejadian Pre Eklampsia pada Ibu Hamil Trimester III yang melakukan Senam Prenatal Yoga

\begin{tabular}{|c|c|c|c|}
\hline Variabel & Kategori & $\mathrm{n}=42$ & $\%=100$ \\
\hline \multirow[t]{2}{*}{ Kejadian Pre Eklampsia } & $\mathrm{Ya}$ & 3 & 7,14 \\
\hline & Tidak & 39 & 92,86 \\
\hline \multirow[t]{2}{*}{ Melakukan senam } & $\mathrm{Ya}$ & 10 & 23,80 \\
\hline & Tidak & 32 & 76,19 \\
\hline
\end{tabular}

\section{Analisis Bivariat}

Analisis bivariat untuk mengetahui pengaruh antara senam prenatal Yoga dengan kejadian pre eklampsia di Puskesmas wilayah kerja Dinkes Kota Bandar Lampung Tahun 2017. Tabel 2 menunjukkan ibu hamil yang melakukan senam prenatal Yogaberjumlah $7 \%$ yang mengalami pre eklampsia dan ibu hamil yang tidak melakukan senam prenatal Yogaterdapat $24 \%$ yang mengalami pre eklampsia. Sedangkan, ibu hamil yang tidak mengalami pre eklampsia berjumlah 93\% yang melakukan senam prenatal Yoga dan 76\% pada kelompok yang tidak melakukan senam prenatal Yoga.

Hasil uji statistik pada tabel 2 memperlihatkan ada pengaruh senam prenatal Yoga terhadap kejadian pre eklampsia ( $p$ value 0,035 ). Nilai OR 2,46 artinya ibu hamil yang melakukan senam prenatal Yoga berpeluang tidak mengalami pre eklampsia sebesar 2,46 kali dibandingkan dengan ibu hamil yang tidak melakukan senam prenatal Yoga.

Tabel 2.

Analisis Pengaruh Antara Senam Prenatal Yoga dengan Kejadian Pre Eklampsia

\begin{tabular}{|c|c|c|c|c|c|c|c|c|}
\hline \multirow{3}{*}{ Senam Prenatal Yoga } & \multicolumn{4}{|c|}{ Kejadian Pre Eklampsia } & \multirow{2}{*}{\multicolumn{2}{|c|}{ Total }} & \multirow{3}{*}{$\begin{array}{c}P \\
\text { value }\end{array}$} & \multirow{3}{*}{ OR } \\
\hline & \multicolumn{2}{|c|}{ Ya } & \multicolumn{2}{|c|}{ Tidak } & & & & \\
\hline & $\mathrm{n}=\mathbf{1 3}$ & $\%$ & $n=71$ & $\%$ & $\mathbf{n}$ & $\%$ & & \\
\hline Melakukan & 3 & 7 & 39 & 93 & 42 & 100 & 0.035 & 2,46 \\
\hline Tidak Melakukan & 10 & 24 & 32 & 76 & 42 & 100 & & $(0,62-9,71)$ \\
\hline
\end{tabular}

Tabel 3 menunjukkan usia ibu hamil $<20$ th dan $>35$ tahun yang lebih berisikoberjumlah $33 \%$ yang mengalami pre eklampsia. Sedangkan, ibu hamil yang tidak mengalami pre eklampsia terdapat67\% pada kelompok usia $<20$ th dan $>35$ tahun. Berdasarkan hasil uji statistik menunjukkan ada pengaruh usia ibu hamil dengan kejadian pre eklampsia ( $p$ value 0,020). Sedangkan, hasil analisis lain memperlihatkan tidak ada hubungan antara spasing, paritas, riwayat pre eklampsia dan kegemukan dengan kejadian pre eklampsia.

\section{Pembahasan}

Hasil penelitian menunjukkan ada pengaruh senam prenatal Yoga dengan kejadian preeclampsia. Sebanyak 42 ibu hamil yang memenuhi syarat sesuai kriteria inklusi dan eksklusi diberikan latihan tentang senam prenatal Yoga di Puskesmas dan selanjutnga diteruskan di rumah. Ibu tersebut dibekali dengan audio CD dan buku tentang senam prenatal Yoga. Senam ini dilakukan pada ibu hamil yang memasuki trimester II dimana kondisi kandungan ibu hamil sudah stabil dan kuat serta plasenta sudah mulai terbentuk.

Senam Yoga bagi kesehatan dapat menurunkan tekanan darah, detak jantung dan meningkatkan peredaran darah untuk membuang sisa-sisa makanan yang mengandung racun bagi tubuh. Selain itu juga latihan Yoga selama hamil dapat meringankan edema dan kram yang sering terjadi pada bulan-bulan terakhir kehamilan, membantu posisi bayi dan pergerakan, meningkatkan system pencernaan dan nafsu makan, meningkatkan energy dan memperlambat metabolisme untuk memulihkan ketenangan dan 
fokus, mengurangi rasa mual, morning sickness dan suasana hati, meredakan ketegangan di sekitar leher hahim dan jalan lahir yang berfokus pada membuka pelvis

Tabel 3.

Analisis Hubungan antara Karakteristik Ibu Hamil Trimester III dengan Kejadian

\begin{tabular}{|c|c|c|c|c|c|c|c|c|}
\hline \multirow{3}{*}{ Variabel } & \multicolumn{4}{|c|}{ Kejadian Pre Eklampsia } & \multirow{2}{*}{\multicolumn{2}{|c|}{ Total }} & \multirow{3}{*}{$P$ value } & \multirow{3}{*}{ OR } \\
\hline & \multicolumn{2}{|c|}{ Ya } & \multicolumn{2}{|c|}{ Tidak } & & & & \\
\hline & $\mathbf{n}$ & $\%$ & $\mathbf{n}$ & $\%$ & $\mathbf{n}$ & $\%$ & & \\
\hline \multicolumn{9}{|l|}{ Umur } \\
\hline$<20$ th $\&>35$ th & 5 & 33 & 10 & 67 & 15 & 100 & \multirow[t]{2}{*}{0.020} & 4.428 \\
\hline $20-35$ tahun & 7 & 10 & 62 & 90 & 69 & 100 & & $(1.174-16.709)$ \\
\hline \multicolumn{9}{|l|}{ Spasing } \\
\hline$\leq 2$ tahun & 6 & 26 & 17 & 74 & 23 & 100 & \multirow[t]{2}{*}{0.058} & \\
\hline$>2$ tahun & 6 & 10 & 33 & 90 & 61 & 100 & & \\
\hline \multicolumn{9}{|l|}{ Paritas } \\
\hline Primipara & 3 & 17 & 15 & 83 & 18 & 100 & \multirow[t]{2}{*}{0.745} & \\
\hline Multipara & 9 & 14 & 57 & 86 & 66 & 100 & & \\
\hline \multicolumn{9}{|c|}{ Riwayat Preeklampsia } \\
\hline Ya & 3 & 23 & 10 & 77 & 13 & 100 & \multirow[t]{2}{*}{0.324} & \\
\hline Tidak & 9 & 13 & 62 & 87 & 71 & 100 & & \\
\hline \multicolumn{9}{|l|}{ Kegemukan } \\
\hline Ya & 6 & 15 & 34 & 85 & 40 & 100 & \multirow[t]{2}{*}{0.858} & \\
\hline Tidak & 6 & 14 & 38 & 86 & 44 & 100 & & \\
\hline
\end{tabular}

pelvis untuk mempermudah persalinan, membantu dalam perawatan pasca melahirkan dengan mengembalikan uterus, perut dan dasar panggul, mengurangi ketegangan, cemas dan depresi selama hamil, persalinan, nifas dan ketidaknyamanan payu dara.

Beberapa hasil penelitian sebelumnya mengatakan bahwa tingkat kehamilan yang berhubungan dengan tekanan darah tinggi juga lebih rendah pada kelompok Yoga. Menurut Narendran (2009) dari Cincinnati Children's Hospital dan Medical Center di Ohio, pengaruh dari latihan Yoga dapat meningkatkan hasil kehamilan yang meliputi peningkatan aliran darah ke plasenta, penurunan hormone stress yang berasal dari ibu dan penurunan produksi hormone yang memicu kelahiran premature. Senam hamil Yoga dan meditasi dapat mengarahkan ibu hamil lebih tenang dan aman karena mengurangi stress psikologis dan cedera fisik selama masa kehamilan dan persalinan, termasuk kecemasan dan rasa sakit (Nerendran, 2009).

Data hasil penelitian menunjukkan adanya kemungkinan bahwa rutinitas olahraga jika dimulai sebelum kehamilan dan dipertahankan melalui masa kehamilan mungkin merupakan cara yang penting bagi wanita untuk mengurangi risiko pre eklampsia. Masih ada beberapa pertanyaan yang masih belum terjawab, seperti, kapan dan berapa banyak latihan olahraga yang diperlukan dan apakah latihan olahraga harus dimulai sebelum kehamilan untuk efek menguntungkan ini terjadi. Selain itu, perlunya penelitian lebih lanjut untuk menentukan tingkat keamanan dapat digunakan sebagai modalitas terapi untuk mengatasi hipertensi yang disebabkan oleh aliran darah yang tidak cukup dalam plasenta.

Berdasarkan hasil penelitian pada manusia dan hewan, disarankan bahwa aktivitas fisik atau olahraga secara teratur selama kehamilan tampaknya akan mengurangi risiko seorang wanita hamil untuk terkena hipertensi dan pre-eklamsia. Ibu hamil menjaga berat badan dan berolahraga selama 2030 menit sehari, 3-5 hari seminggu sudah cukup untuk mencegah preeklamsia. Olahraga yang direkomendasikan adalah olahraga yang tidak terlalu berat dan aman dijalankan oleh ibu hamil, seperti senam Yoga, jalan cepat, senam khusus ibu hamil dan renang. 
Senam prenatal Yoga selama kehamilan dalam upaya melancarkan peredaran darah dan memberikan ketenangan kepada ibu hamil dalam menghadapi kehamilannya sampai menghadapi persalinannya nanti. Bidan memiliki peran dalam memberikan asuhan kepada ibu hamil antara lain memberikan pengetahuan terhadap ibu hamil dan keluarganya pentingnya mempersiapkan kehamilannya dengan baik antara lain gizi selama kehamilan dan kebutuhan istirahat selama hamil.

Pada saat kehamilan, ibu hamil mengalami banyak perubahan baik fisik maupun psikologis, perasaan ketidaknyamanan, perasaan mual dan muntah, letih dan adanya penurunan keinginan seksual (Bobak, Lowdermilk, Jensen, \& Perry, 2005). Hal tersebut disebabkan adanya peningkatan hormon estrogen dan progesteron. Salah satu perubahan yang diakibatkan adanya kehamilan berkaitan dengan perubahan pada psikologis, yaitu adanya rasa khawatir dan was-was berkaitan dengan kehamilannya.Oleh karena itu, ibu hamil perlu diberikan penyuluhan dan latihan tentang senam Yoga dalam masa kehamilannya.

Senam prenatal Yoga merupakan kesatuan antara tubuh, pikiran dan jiwa, yaitu kesatuan antara individu dan intelegensi yang mengatur alam semesta (Indika, 2016). Keadaan dimana semua komponen dan kekuatan yang membentuk organisasi biologis berinteraksi secara harmonis dengan komponenkomponen alam semesta yang dapat menimbulkan kesejahteraan emosional, psikologis dan spiritual serta keinginan diri.

Latihan senam prenatal Yoga terkandung efek relaksasi yang dapat menstabilkan emosi ibu hamil, sebab gerakan senam hamil Yoga memfokuskan perhatian pada ritme nafas, mengutamakan kenyamanan serta keamanan dalam berlatih sehingga memberikan banyak manfaat (Krisnadi, 2010). Latihan relaksasi pada senam prenatal Yoga, menggabungkan antara relaksasi otot dan relaksasi pernafasan dengan cara ibu hamil melakukannya sambil membayangkan keadaan bayi didalam perut baik-baik saja. Selain itu, kesiapan psikologis berkaitan dengan perasaan cemas, stress dan takut merupakan masalah yang sering dialami oleh ibu hamil trimester III dalam menghadapi persalinan. Berdasarkan hal tersebut, maka untuk memutuskan siklus kecemasan dan meningkatkan kesiapan ibu hamil menghadapi persalinan perlu dilakukan kegiatan senam prenatal Yoga secara teratur dan terprogram disetiap kelas ibu.

Berkaitan dengan manfaat dari senam prenatal Yoga terhadap ketenangan ibu hamil dalam menjalankan masa kehamilan dan mempersiapkan persalinannya, perlu diprogramkan pada pelaksanaan kelas ibu hamil senam prenatal Yoga yang dilakukan 2-3 kali seminggu selama 90 menit. Selain itu, juga ibu hamil disarankan untuk melakukannya di rumah agar terwujud perasaan tenang dan releksasi sehingga peningkatan tekanan darah pada kehamilan diharapkan terkendali karena dapat memicu terjadinya pre eklampsia pada masa kehamilan dan persalinan yang merupakan salah satu penyebab terjadinya kematian ibu pada kehamilan dan persalinan.

\section{Simpulan dan Saran}

Ibu hamil yang melakukan senam prenatal Yoga terdapat 7,14\% yang mengalami pre eklampsia, sedangkan yang tidak melakukan senam prenatal Yoga terdapat 23,80\% yang mengalami pre eklampsia. Senam prenatal Yoga yang dilakukan ibu hamil dapat mencegah kejadian pre eklampsia pada trimester III. Perlunya upaya memprogramkan pelaksanaan senam prenatal Yoga dimulai pada awal trimester II baik di Puskesmas maupun di Poskeskel pada kegiatan kelas ibu dan mengevaluasi sejauh mana pelaksanaan senam prenatal Yoga yang dilakukan ibu hamil di rumah.

\section{Referensi}

Alimul, A. H. (2011). Metode penelitian kebidanan teknik analisis data. Jakarta: Salemba Medika.

Bobak, I. M., Lowdermilk, D. L., Jensen, M. D., \& Perry, S. E. (2005). Buku ajar keperawatan maternitas. Jakarta: Buku Kedokteran 2005. 
Pengaruh Senam Prenatal Yogaterhadap Kejadian Pre Eklampsia pada Ibu Hamil Trimester III ... Rosmadewi Rosmadewi, Novita Rudiyanti

Jurnal Kesehatan Metro Sai Wawai. 11 ( 1) 2018. E-ISSN 2657-1390. P-ISSN19779-469X

Depkes, R.I. (2009). Angka kematian ibu melahirkan (AKI). Retrieved from dari http://www. Menegpp.go.id/aplikasi data.php tanggal 3 Maret 2011.

Depkes, R.I. (2010). Strategi akselerasi pencapaian target MDGs2015. Retrieved from darihttp://www.target_MDGs. Tanggal 13 Januari 2011.

Dinkes kota Bandar Lampung. (2014). Profil kesehatan Bandar Lampung. Bandar Lampung: Dinkes kota Bandar Lampung.

Dinkes Provinsi Lampung. (2015). Profil kesehatan Lampung. Bandar Lampung: Dinkes Provinsi Lampung.

Fatkhiyah, N. (2013). Kepatuhan bidan dalam deteksi preeklampsia. Makalah disampaikan dalam presentasi hasil-hasil penelitian lustrum ke-3. Unimus Semarang.

Hasnawati, D. (2014). Faktor-faktor yang berhubungan dengan kejadian pre eklampsi pada kehamilan di RSUD Embung Fatimah kota Batam Tahun 2012. Jurnal Kesehatan Andalas, 3 (2), 28-31. doi:https://doi.org/10.25077/jka.v3.i1.p\%25p.2014

Hastuti, S. P. (2015). Faktor-faktor yang berhubungan dengan kejadian preeklampsia kehamilandi wilayah kerja Puskesmas Pamulang Kota Tangerang Selatan Tahun 2014-2015. Skripsi. Jakarta: Fakultas Kedokteran Dan Ilmu Kesehatan UIN Syarif Hidayatullah Jakarta.

Heri, P. (1999). Pengantar perilaku manusia untuk keperawatan. Jakarta: Buku Kedokteran EGC.

Ikatan Bidan Indonesia. (2006). Bidan menyongsong masa depan-IBI 50 tahun. Jakarta: Depkes RI.

Indiarti, M. T. (2009). Panduan lengkap kehamilan, persalinan dan perawatan bayi. Jakarta: Diglossia Media.

Indika, Y. M. (2016). Senam hamil dan prenatal yoga. Diakses 29 Januari 2016.

Kemenkes RI. (2015). Angka Kematian Ibu Retieved from www.depkes.go.id > download > pusdatin > infodatin .

Kemenkes RI. (2016). Profil kesehatan Indonesia. Jakarta: Kemenkes RI.

Kemnekes RI. (2016). Profil kesehatan Indonesia. Jakarta: Kemnekes RI.

Krisnadi, S. R. (2010). Sinopsis yoga untuk kehamilan sehat, bahagia dan penuh makna. Retieved http/www.bukukia.com. tanggal 13 Januari 2011.

Lemeshow, S., \& David, J. (1997). Besar sampel dalam penelitian kesehatan. Yogjakarta: Universitas Gajah Mada Press.

Manuaba, I. A. (2009). Memahami kesehatan RS reproduksi wanita (2 ed.). Jakarta: Buku Kedokteran EGC.

Nerendran, S. (2009). Yoga inproves pregnancy outcomes source. Journal of Alternative and Complementary Medicine, 2005; 11: 237-44.

Notoadmodjo, S. (2007). Perilaku kesehatan. Jakarta: Rineka Cipta.

Prawirohardjo, S., Anwar, M., Baziad, A., \& Prabowo. (2011). Ilmu kandungan. Edisi 3. Jakarta: PT Bina Pustaka.

Priyo, H. S. (2007). Priyo, H.S. Analisa data kesehatan. Depok: FKM UI.

Rusmita, E. (2015). Pengaruh senam hamil yoga terhadap kesiapan ibu hamil menghadapi persalinan di RSIA Limijati Bandung. Jurnal Ilmu Keperawatan, 3 (2). 80-86.

Sindhu, P. (2009). Yoga untuk kehamilan sehat, bahagia dan penuh makna. Bandung: Qonita, Mirzan Pustaka.

Siska, \& Connie. (2009). Siapa bilang yoga sulit. Jakarta: Intisari Mediatama.

Sutijono, A. (2007). Pengantar statistik pendidikan. Jakarta: Raja Grafindo Persada. 